\title{
EXPERIMENTAL INVESTIGATION ON THE VARIABILITIES OF THE ELASTIC PROPERTIES OF AMAZONIAN HARDWOOD CORDIA GOELDIANA
}

\author{
Ribeiro RFS*, Feiteira JFS, de Gouvêa JP \& Ferreira AF \\ FederalFluminense University - PPGEM, Av. dos Trabalhadores 420, Vila S. Cecília, 27255125, Volta Redonda, RJ Brazil \\ *roseliribeiro@id.uff.br
}

Received March 2020; accepted November 2020

\begin{abstract}
Variabilities in dynamic elastic modulus and density of three wooden pieces of Amazonian species Cordia goeldiana were experimentally investigated and discussed. Wooden pieces belonging to different trees were purchased from the common internal timber market of Brazilian southeast region. Sixteen specimens were cut and prepared from each wooden piece in order to obtain elastic modulus via impulse excitation technique. Statistical processing of data was performed to compare between samples. Two wooden pieces exhibited similarities, presenting lower variabilities and higher values of elastic modulus and density. In addition, anatomical analysis was conducted on the wooden piece with larger variability, taking into account average diameter of pores and fibres, pores frequency and area occupied by pores. Investigation of relationships between anatomical features and elastic values showed weak or very weak correlations.
\end{abstract}

Keywords: Impulse excitation technique, Sonelastic, Kruskal Wallis, soundboard acoustic guitar, wood anatomical analysis

\section{INTRODUCTION}

In Brazilian musical instruments sector, high costs and shortage of traditional wood species, for use in acoustic and electric guitars, have led to an increasing demand for suitable "nontraditional" wood that is able to provide quality instruments. In this context, studies focusing on mechanical and acoustic characteristics of Brazilian species have been carried out (Marques et al. 2006, Portela 2014). Slooten and Souza (1993) investigated Amazonian species and proposed a list likely to be suitable for string and wind instruments. The general characteristics (color, texture, figure and grain), physical and mechanical properties (specific gravity, shrinkage, static bending and compression parallel to the grain), dimensional stability under different climatic conditions, and acoustical and machining features were determined. Three prototypes were manufactured using freijó (Cordia goeldiana), muiracatiara, marupá, tauari, urucu da mata, gombeira and faveira folha fina, where volume, balance, decay, undesirable resonances, brightness and weight were examined.

According to Gomes (1982), C. goeldiana (among other similar species that compose
Cordia genus) has undergone intense selective harvesting. This species has been used in furniture, panels, window, door systems and, currently, in guitar body construction. Previous researches investigated subjects like finishing products, particleboards, growth rates and anatomical identification (Christoforo et al. 2015, Bufalino et al. 2014, Gonçalez et al. 2010). Social and economic importance of this wood led to the proposition of suitable areas for implantation of genetic reserves (in situ conservation) and germplasm banks (ex situ conservation) (Leite e Lleras 1993). The viability of its rational cultivation in different silvicultural systems was also investigated (Yared 1992).

In general, researches related to musical instruments seek to understand vibroacoustic behavior because it determines quality of sound emitted when instrument is played. Such quality is defined according to type and purpose of the product and have been quantified by means modal parameters (natural frequencies, damping and quality factor), which determines tone, decay and volume of sound produced. In this context, two issues can be raised: on one hand, it is known that modal parameters are 
affected by elastic properties and density, and on the other hand, wood can present several patterns of variability in its properties (Cruz et al. 2003, Valente et al. 2013, Melo et al. 2013, Araújo et al. 2016). Taking this into account, it is relevant to consider how the natural variability, important for dynamic analysis of wood structures, interferes with sound response, especially for standardisation of musical instruments. In this regard, the present work focused on investigating the elastic modulus and density variabilities of three wooden pieces of C. goeldiana, aiming to analyse how these variabilities affect vibroacoustic responses of acoustic and electric guitar in numerical models (Figure 1). Due to scarcity of supply of non-traditional Brazilian woods, treated for musical instruments, wooden pieces were purchased from the common internal timber market of Brazilian southeast region, each one belonging to a different batch. Impulse excitation technique (IET) was employed for acquisition of dynamic elastic modulus. In addition, with the intention of finding alternative approaches for the examination and selection of suitable wooden pieces, the relationship between elastic properties and specific transversal features of anatomical elements were inspected.

\section{Impulse excitation technique (IET)}

The IET is a dynamic method widely employed to obtain elastic properties and functionalities. This technique has an advantage over static methods, allowing to test the same specimen several times. Structures can vibrate naturally in many different ways according to its geometry and boundary conditions. These different ways of vibration, called mode shapes or modes of vibration, can be longitudinal, flexural or torcional and have their own frequencies, depending on the material that composes it. When a body receives a short and slight impact, one or more of its mode shapes are excited and a sound signal composed by all related frequencies is generated. In these vibrations, regions without movement known as nodal regions are observed, and others in which the amplitude of vibration is maximal (Figure 2). Extraction of natural frequencies from sound signal is possible by fast Fourier transform (Heideman et al.

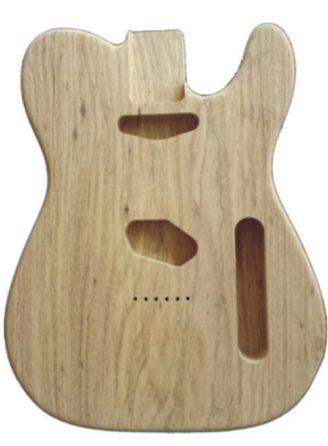

Electric guitar body

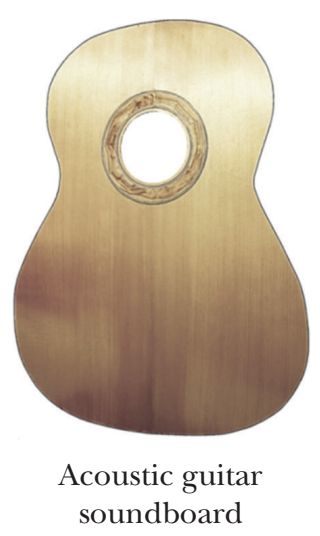

Acoustic guitar
soundboard

Figure 1 Electric guitar body and acoustic guitar soundboard, components of string musical instruments
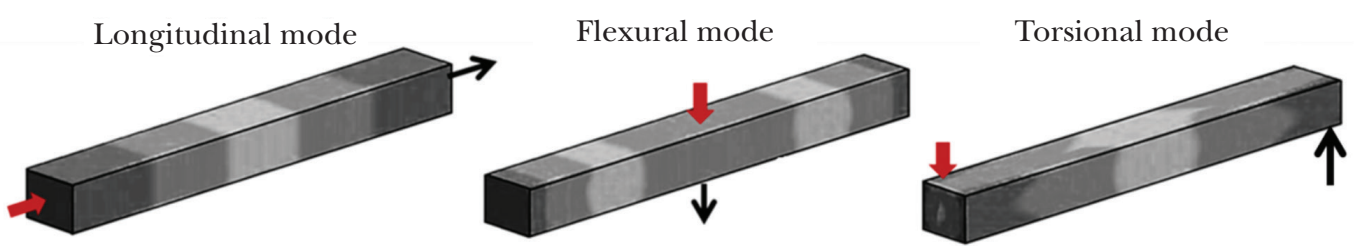

Figure 2 Mode shapes in rectangular geometry specimens (lighter areas indicate nodal regions and darker areas indicate the greatest amplitudes), red arrows point to direction and orientation for application of impulse, and blue arrows assign region for sound response acquisition (Otani Pereira 2016) 
1985). Mathematical relations between elastic modulus, density and fundamental natural frequency have been reported for specimens with regular shapes (Pickett 1945, Spinner et al. 1960, Spinner \& Tefft 1961, Barboni et al. 2018). These relationships and the concepts of mode shape, frequency and nodal region are taken into account in IET for elastic modulus evaluation.

The following equations express the relationship between longitudinal elastic modulus and fundamental frequency in a rectangular cross section specimen, when longitudinal mode is considered (Spinner \& Tefft 1961):

$$
\mathrm{E}_{\mathrm{d}}=4 * \mathrm{~m} * \mathrm{f}_{1}^{2} *\left[\frac{\mathrm{L}}{\mathrm{b} * \mathrm{t} * \mathrm{~K}}\right]
$$

where $\mathrm{L}=$ specimen length $(\mathrm{mm}), \mathrm{m}=$ specimen mass $(g), f_{1}=$ fundamental natural frequency $(\mathrm{Hz}), \mathrm{b}=$ specimen width $(\mathrm{mm}), \mathrm{t}=$ specimen thickness $(\mathrm{mm})$ and $\mathrm{K}=$ correction factor

$$
\mathrm{K}=1-\left[\frac{\pi^{2} * \mu^{2} * \mathrm{D}_{\mathrm{e}}^{2}}{8 * \mathrm{~L}^{2}}\right]
$$

where $\mu$ - Poisson's ratio, $\mathrm{D}_{\mathrm{e}}=$ effective specimen diameter $(\mathrm{mm})$

$$
\mathrm{D}_{\mathrm{e}}^{2}=2 * \frac{\mathrm{b}^{2}+\mathrm{t}^{2}}{3}
$$

The overall quality of approximation is quite good, with errors smaller than $0.1 \%$ for length/ width ratios larger than 3 (Lord and Morrell 2006).

\section{MATERIALS AND METHODS}

Three planks of C. goeldiana were randomly selected from the internal market of Brazilian southeast region. In order to ensure that the timber planks belonged to distinct trees, different batches were investigated. Three pieces were cut and named piece 01 , piece 02 and piece 03 . Average dimensions were $1000 \mathrm{~mm}$ length, 280 $\mathrm{mm}$ width and $40 \mathrm{~mm}$ thickness. Since it was not possible to select planks from a larger number of trees, the results cannot be generalised, but serves as a database for further investigations. Sixteen specimens were extracted from each wooden piece; dimensions were in accordance to Lord and Morrell (2006) for application of IET (Figure 3a). The length was cut parallel to fibre directions so that longitudinal elastic modulus could be obtained. A total of 48 specimens were examined (Figure 3b).

The specimen surfaces were mechanically flattened and polished by using abrasive papers (80-1000 grit). At the end of the sanding process, dimensions were measured using a digital caliper with precision $1 \times 10^{-2} \mathrm{~mm}$, and masses were determined by using a digital electronic balance with precision $1 \times 10^{-2} \mathrm{~g}$. The specimens were kept in an air-conditioned room at temperature $22^{\circ} \mathrm{C}$ and relative humidity $56 \% \mathrm{RU}$ for a period of not less than two months. For implementation of IET, Sonelastic ${ }^{\circledR}$ system for medium-sized specimens was employed (Figure 4). The apparatus comprised of support system, acoustic sensor, tapping device and software to process the sound response. Experimental procedures were conducted in the Mechanical Characterisation Laboratory, Federal Fluminense University-Volta (a)

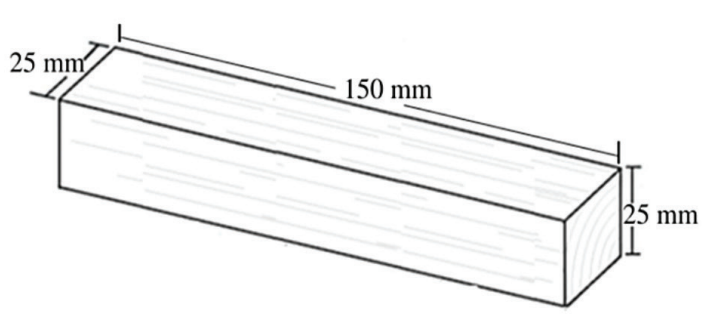

(b)

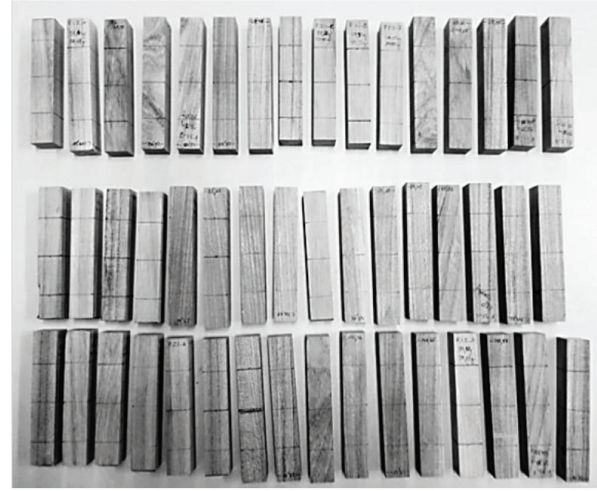

Figure 3 (a) Standard specimen dimensions for evaluation of longitudinal dynamic elastic modulus (impulse parallel to fibre), (b) wood specimens analysed in the present study 

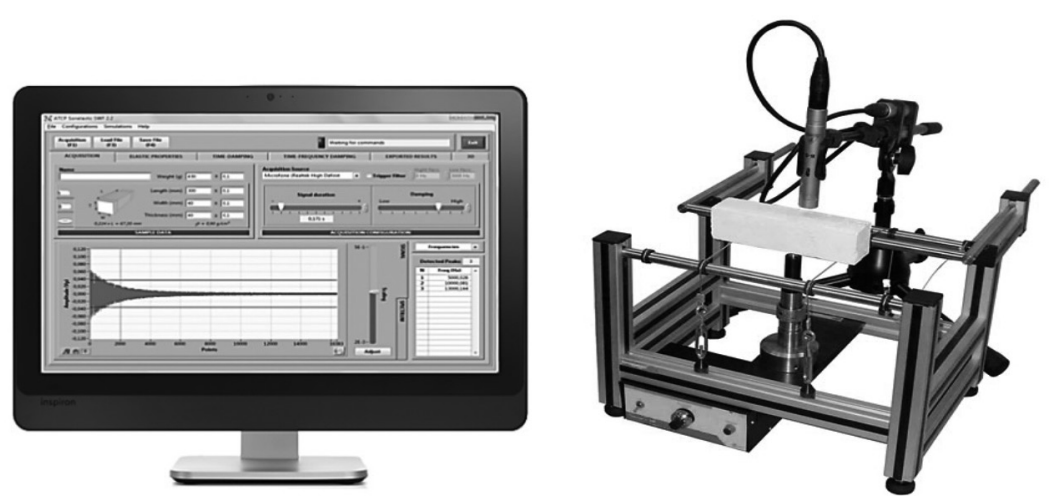

Figure 4 Sonelastic $®$ system

Redonda School of Industrial Metallurgical Engineering (UFF-EEIMVR).

For evaluation of longitudinal elastic modulus, parallel to wood fibre, through longitudinal mode of vibration, acoustic sensor were positioned perpendicular to the cross section of the specimen and impulse was applied on the opposite side (Lord and Morrell 2006) (Figure 5). In order to support the specimen, nodal regions of flexural mode were preferred over those of longitudinal mode. In the first case, a greater stability was reached and no significant differences were visualised in resulting elastic modulus value. Five repetitions were performed for each specimen so that a total of 240 tests were conducted. Densities were calculated by dividing mass by volume.

Sixteen values of elastic modulus and densities were acquired for each wooden piece examined. In the inference analysis of data sets, assumptions for application of ANOVA were explored (Rocha and Júnior 2018). Since at least one of the assumptions were not met, significant difference was verified by Kruskal Wallis, a non-parametric test analogue of one-way ANOVA (Mair and von Eye 2005, Hecke 2010). Statistical software PAST 3.26 was used in the present study.
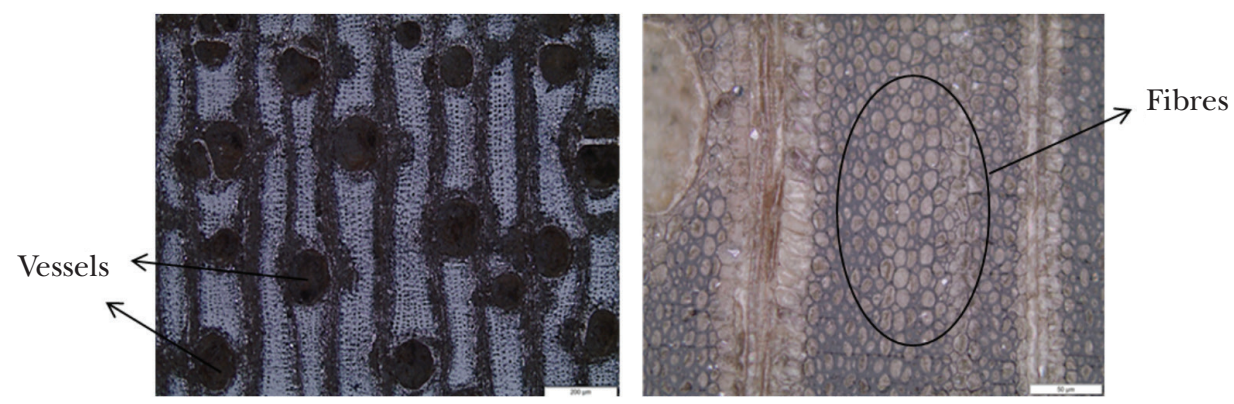

Figure 6 Anatomical elements exposed in transversal section; scale bar - image on the left: $200 \mu \mathrm{m}$, image on the right: $50 \mu \mathrm{m}$

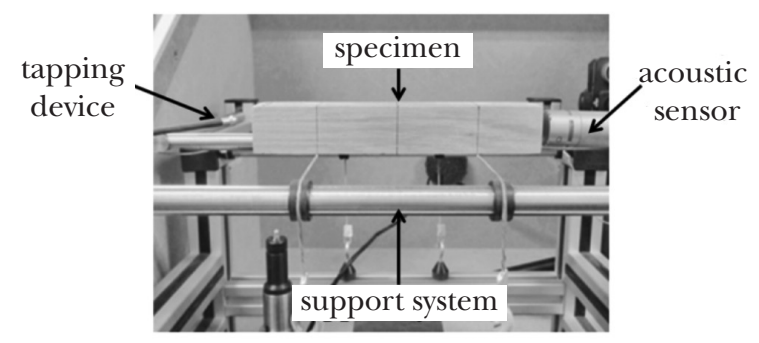

Figure 5 Position of specimen at the support system, points of impact and vibration capture

At the end of the mechanical characterisation process, one end of the specimens belonging to the wooden piece that showed greatest variability, was cut out for anatomical analysis under optical microscope. In the method adopted for surface finishing process, gradual sanding was performed with abrasives P320-2500 for contours of cellular elements (Figure 6). Pores frequency (pores $\mathrm{mm}^{-2}$ ), fibre and pore diameters, as well as area occupied by pores were measured in seven regions of a specific specimen slice. Relationships between elastic modulus and anatomical features were inspected. 


\section{RESULTS AND DISCUSSION}

Figure 7 shows the spectrum of sound signal emitted by specimens under impulsive load. Peaks represent fundamental frequencies of longitudinal vibratory excited mode. This frequency was used for $E_{d}$ evaluation.

Figure 8 shows dot plot graphs for elastic modulus and density. Different patterns of variability were observed between pieces 01 , 02 and 03. By Tukey's method, the two lowest dots in $E_{d}$ data set of piece 01 were statistically considered outliers (observations that lie in abnormal distance from the majority in data set) (Rousseeuw and Hubert 2018). No errors were found in the general measurement process of mechanical properties; these abnormal values were related to natural morphological features of wood (Burger and Richter 1991). Removal of outliers was accomplished in statistical processing, since they were responsible for main discrepancies between data sets of pieces 01 and 03. This led to unrepresentative changes in the mean (about 3\%) and significant decrease in standard deviation (Table 1).

After discarding the outliers, the normality of respective sample residuals were confirmed by Shapiro-Wilk W test at significance level $5 \%$. Normality of residuals is one of the assumptions required for ANOVA. Another assumption required for ANOVA is homoscedasticity of residuals (Mair and von Eye 2005). The hypothesis was inspected by Fisher-Snedecor distribution and its heteroscedasticity verified, at significance level $5 \%$, due to the large scattering in piece $02\left(\mathrm{E}_{\mathrm{d}}\right.$ and density values presented similar behavior). In the case of heteroscedasticity, nonparametric approaches such as Kruskal-Wallis test is recommended (Mair and von Eye 2005, Hecke 2010).

To obtain critical values, statistical test $\mathrm{H}$ of Kruskal-Wallis was applied and $\chi^{2}$ distribution was used at significance level $5 \%$ and 2 degrees of freedom, and the following results were computed:

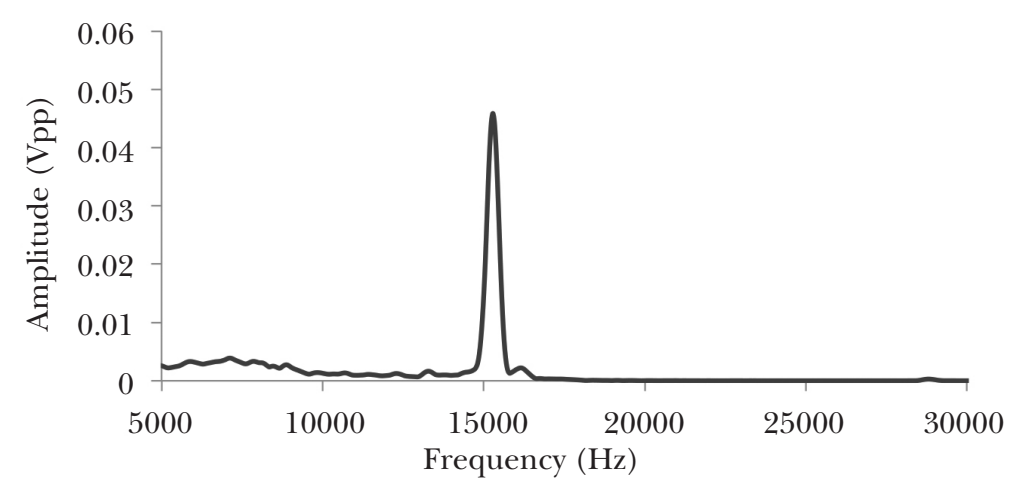

Figure 7 Frequency spectrum of sound signal emitted by one of the specimens tested

(a)

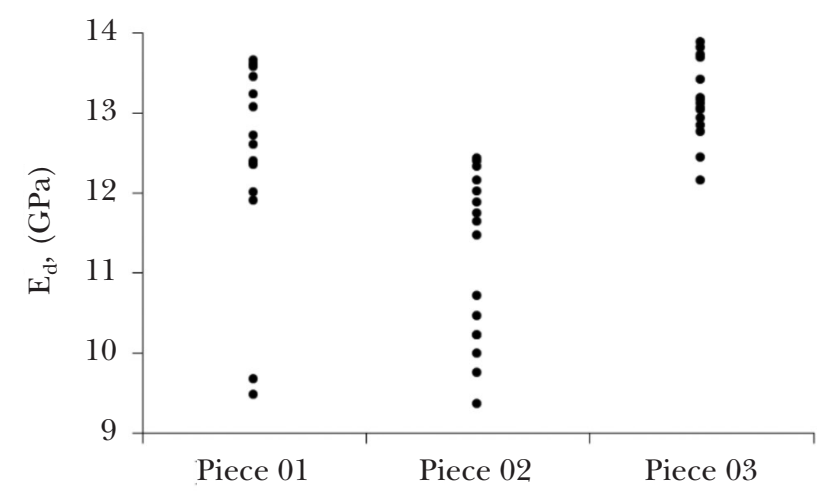

(b)

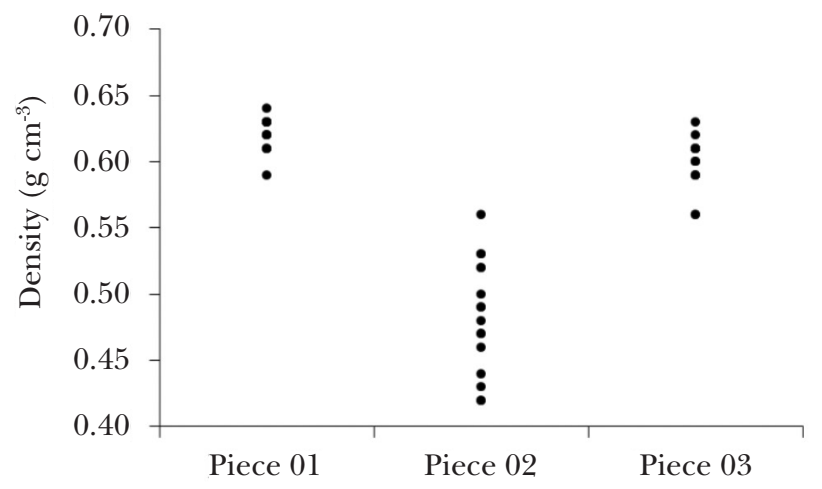

Figure 8 (a) Elastic modulus evaluated for Pieces 01, 02 and 03, (b) densities evaluated for pieces 01,02 and 03 
Table 1 Statistics for Pieces 01, 02 and 03

\begin{tabular}{|c|c|c|c|c|c|c|}
\hline & \multicolumn{2}{|c|}{ Piece 01} & \multicolumn{2}{|c|}{ Piece 02} & \multicolumn{2}{|c|}{ Piece 03} \\
\hline & $\begin{array}{l}\text { Density } \\
\left(\mathrm{g} \mathrm{cm}^{-3}\right)\end{array}$ & $\begin{array}{c}\mathrm{E}_{\mathrm{d}} \\
(\mathrm{GPa})\end{array}$ & $\begin{array}{l}\text { Density } \\
\left(\mathrm{g} \mathrm{cm}^{-3}\right)\end{array}$ & $\begin{array}{c}\mathrm{E}_{\mathrm{d}} \\
(\mathrm{GPa})\end{array}$ & $\begin{array}{l}\text { Density } \\
\left(\mathrm{g} \mathrm{cm}^{-3}\right)\end{array}$ & $\begin{array}{c}\mathrm{E}_{\mathrm{d}} \\
(\mathrm{GPa})\end{array}$ \\
\hline Min & 0.59 & 11.9 & 0.42 & 9.4 & 0.56 & 12.2 \\
\hline Max & 0.64 & 13.7 & 0.56 & 12.4 & 0.63 & 14.2 \\
\hline Mean & 0.62 & 12.8 & 0.48 & 11.2 & 0.60 & 13.2 \\
\hline Median & 0.63 & 12.7 & 0.49 & 11.6 & 0.61 & 13.2 \\
\hline Standard deviation & 0.01 & 0.62 & 0.04 & 1.04 & 0.02 & 0.55 \\
\hline Coefficient of variation $(\%)$ & 2.07 & 4.82 & 8.77 & 9.3 & 3.16 & 4.14 \\
\hline
\end{tabular}

- For $\mathrm{E}_{\mathrm{d}}: \mathrm{H}=26.26>\chi^{2}=5.99$, p-value $=9.09 \mathrm{E}$ 07 , leading to rejection of same distribution hypothesis in elastic modulus and the conclusion that medians between wooden samples are not equal (at least one median is different)

- For density: $\mathrm{H}=35.79>\chi^{2}=5.99$, $\mathrm{p}$-value $=2.2 \mathrm{E}-08$, leading to rejection of same distribution hypothesis in density and the conclusion that medians between wooden samples are not equal (at least one median is different).

Considering results provided by Githiomi \& Kariuki (2010), which analyzed variation of basic density with age of Eucalyptus grandis, it is likely that higher means added to lesser variabilities of Pieces 01 and 03 are related to an older age of source trees, in comparison to Piece 02. According to Zobel and Sprague (1998), age has a direct effect on properties of wood; relations were established between age and specific gravity. In this context, suitable selection and treatment of non-traditional woods are required for acquisition of good and stable instruments.

Relationships between $\mathrm{E}_{\mathrm{d}}$ and density have also been studied (Figure 9). Regression analysis and line best fit indicated strong correlation for piece 02 , however, the same was not observed for the remaining wooden pieces where weak and null correlations were visualised (Table 2). Considering the proposed hypothesis in respect to age of source trees, these results suggest good correlations between elastic modulus and density for younger wooden pieces.

Figure 10 provides an overview of relationships observed between elastic modulus and anatomical features. As described previously, diameter of pores and fibres, pores frequency and area occupied by pores were measured.
In view of the weak or null correlations exhibited, it was not possible to establish preliminary relationships that allowed estimation of elastic modulus based on anatomical characteristics examined. Nonetheless, the area occupied by pores could be considered in further investigations, in which multivariate regression involving area occupied by fibres, parenchyma and rays could be taken into account. These anatomical features were studied by Uetimane and Ali (2011) in the inspection of Ntholo (Pseudolachnostylis maprounaefolia).

The influence of mechanical properties variability on vibroacoustic response of musical instruments must be investigated using numerical simulation for additional conclusions.

\section{CONCLUSIONS}

Variability characteristics of density and elastic modulus between the three pieces of $C$. goeldiana were acquired in this study. Considering aspects related to stability of mechanical properties, inferential analysis of data sets indicated similarities between pieces 01 and 03 , presenting close variabilities and approximated means for density and $\mathrm{E}_{\mathrm{d}}$ (neglecting of outliers). On the other hand, piece 02 showed significant variability, added to lower values for both parameters.

Taking into account results provided by Githiomi \& Kariuki (2010) and Zobel and Sprague (1998) related to age and basic density/ specific gravity, one could suggest that piece 02 belongs to a younger tree. Correlation between $E_{d}$ and density indicated that, the older the three, the lower the correlation between these properties. A strong Pearson's correlation was observed for piece $02(0.9)$, whereas, for the other pieces tested, no representative linear correlations were verified. 

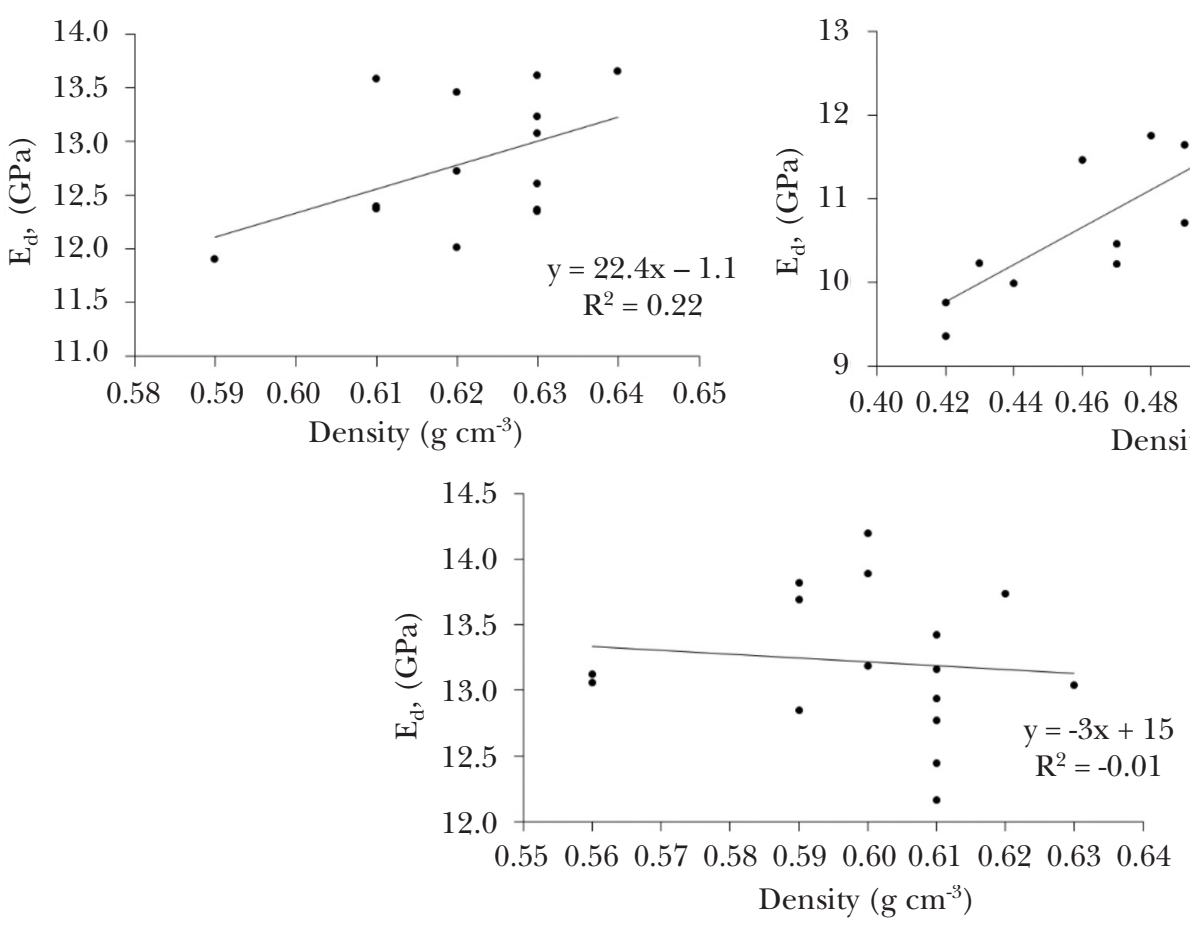

Figure 9 Scatter plot and trend line exhibiting relationship between dynamic elastic modulus and density for pieces 01 (a), 02 (b) e 03 (b); in best fit linear equations, $x$ and y express $\mathrm{E}_{\mathrm{d}}$ and density, respectively
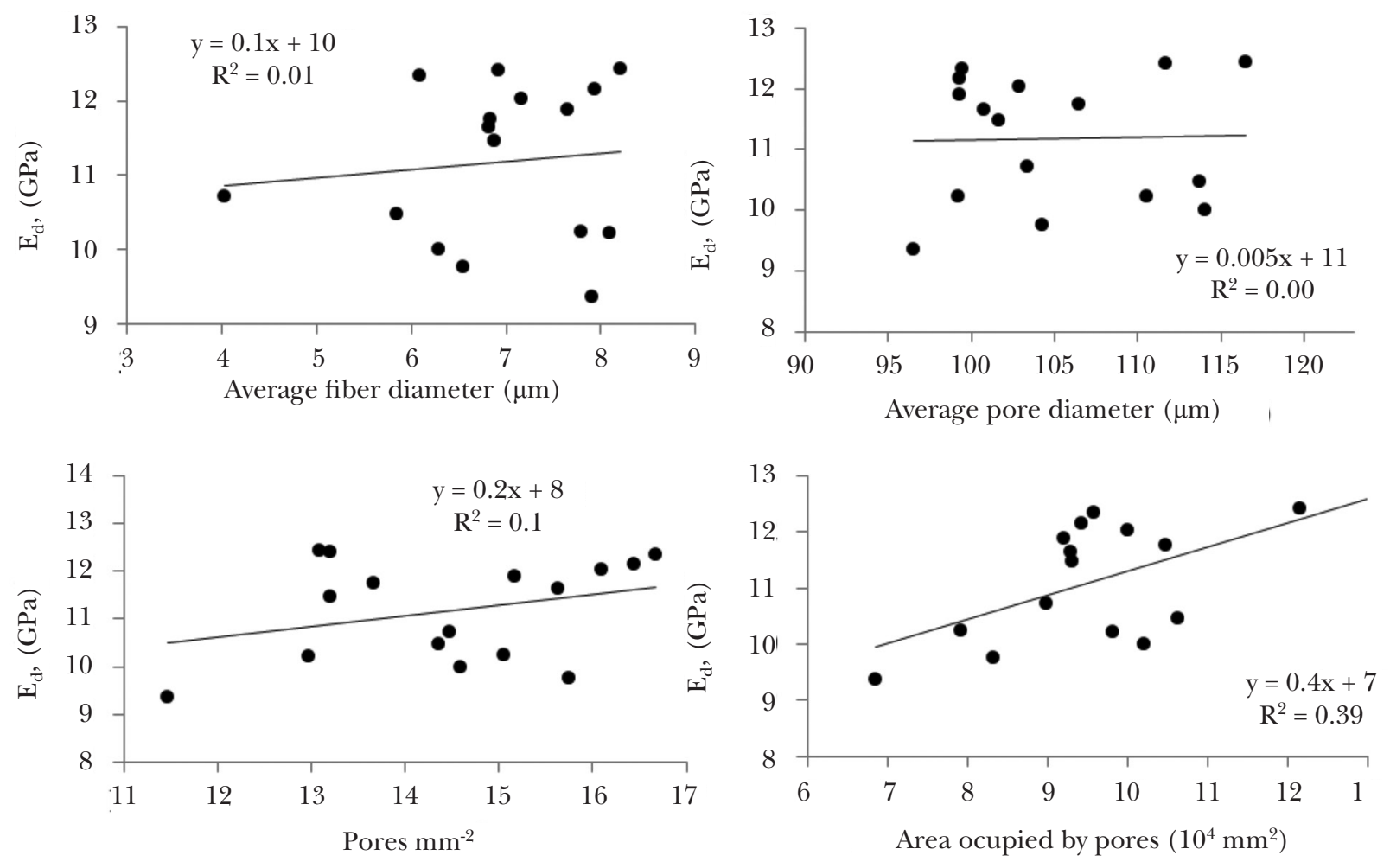

Figure 10 Scatter plots and trend lines exhibiting relationship between dynamic elastic modulus and anatomical features of specimens slices; in best fit linear equations, $\mathrm{x}$ and $\mathrm{y}$ express $\mathrm{E}_{\mathrm{d}}$ and density, respectively 
Table 2 Statistics for least square regression

\begin{tabular}{lccc}
\hline & Piece 01 & Piece 02 & Piece 03 \\
\hline $\mathrm{R}$ & 0.48 & 0.89 & -0.11 \\
$\mathrm{R}^{2}:$ & 0.23 & 0.8 & 0.01 \\
$\mathrm{t}:$ & 1.882 & 7.479 & -0.435 \\
$\mathrm{p}$ (uncorr.) $:$ & 0.084 & $2.97 \mathrm{E}-06$ & 0.67 \\
\hline
\end{tabular}

confidence level $=95 \%$

It was not possible to establish preliminary relationships for estimation of elastic modulus based on anatomical characteristics examined. Nevertheless, further research, in which multivariate regression involving measures of area occupied by pores, fibres, parenchyma and rays should be undertaken.

Means, obtained for each wooden piece, can be used for future application in numerical simulations of string musical instruments. Application of the three different means evaluated can predict the vibroacoustic behavior of instruments, hypothetically manufactured with the respective wooden piece.

\section{ACKNOWLEDGMENTS}

The authors would like to acknowledge the financial support provided by CAPES and Finep.

\section{REFERENGES}

Araújo BHP, Souza MAR, Nascimento HEM, Zanuncio AJV, Rodrigues DDS \& Guedes MC. 2016. Propriedades físicas da madeira de Calycophyllum spruceanum Benth. em função do diâmetro e da posição (base e topo) no fuste. Scientia Forestalis 44: 759-768. doi: 10.18671/scifor.v44n111.22.

Barboni L, Gillich CP, Chioncel CP, Hamat CO \& Mituletu IC. 2018. A method to precise determine the Young's Modulus from dynamic measurements. IOP Conference Series. Materials Science and Engineering 416: 012063. doi:10.1088/1757899X/416/1/012063.

Bufalino L, Mendes LM, Tonoli GHD, Rodrigues A, Fonseca A, Cunha, PI \& Marconcini JM. 2014. New products made with lignocellulosic nanofibres from Brazilian amazon forest. IOP Conference Series. Materials Science and Engineering 64: 012012. doi:10.1088/1757-899X/64/1/012012.

Burger ML \& Richter HG. 1991. Anatomia da Madeira. Nobel, São Paulo.

Christoforo AL, Silva SAM, Barbosa JC, Filho SLMr, Panzera TH \& Lahr FAR. 2015. Produção de chapas de partículas com resíduos de madeira Cordia goeldiana. Engenharia Agrícola 35: 368-377. doi: http://dx.doi.org/10.1590/1809-4430.
Cruz CR, Lima JT \& Muniz GIB. 2003. Variações dentro das árvores e entre clones das propriedades físicas e mecânicas de híbridos de Eucalyptus. Scientia Forestalis 64: 33-47.

Githiomi JK \& Kariuki JG. 2010. Wood basic density of Eucalyptus grandis from plantations in Central Rift Valley, kenya: variation with age, height level and between sapwood and heartwood. Journal of Tropical Forest Science. 22: 281-286.

Gomes JI. 1982. A Madeira de Cordia goeldiana Huber. Research Bulletin No. 45. EMBRAPA-CPATU, Belém.

Gonçalez JC, Félix Tlf, Gouveia FN, Camargos JaA \& RibeIro PG. 2010. Effect of ultraviolet radiation on the color of Freijó wod (Cordia goeldiana Huber) after application of finishing products. Ciência Florestal 4: 657-664.

Hecke TV. 2010. Power Study of Anova Versus Kruskal-Wallis Test. Faculty of Applied Engineering Sciences, University College Ghent, Ghent.

Heideman MT, Johnson DH \& Burrus CS. 1985. Gauss and the history of the fast Fourier transform. Archive for History of Exact Sciences 34: 265-277.

Leite AMC \& Lleras E. 1993. Áreas prioritárias na Amazônia para conservação dos recursos genéticos de espécies florestais nativas: fase preliminar. Acta Botanica Brasilica. 7: 61-94.

Lord JD \& Morrell R. 2006. Measurement Good Practice Guide 98: Elastic Modulus Measurement. National Physical Laboratory, London.

Mair P \& Von Eye A. 2005. Encyclopedia of Statistics in Behavioral Science. Volume 1. John Wiley \& Sons Ltd., Chichester.

Marques MH, Martins VA, Souza MR \& Alves MVS. 2006. Efeito da secagem nas propriedades acústicas da madeira de marupá (Simarouba amara Aubl.). Floresta e ambiente 12: 57-64.

Melo LEL, Silva CJ, Urbinati CV, Santos IS \& Soares WF. 2013. Variação Anatômica no Lenho de Astronium lecointei Ducke. Floram 20: 135-142. doi: 10.4322/ floram.2012.049.

Otani LB \& Pereira AHA. 2016. Estimation of the Static Modulus of Elasticity of Concrete Using the Impulse Excitation Technique. Technical-Scientific Informative ITC-07. Revision 1.2. ATCP Physical Engineering, Sao Carlos. doi:10.13140/RG.2.2.10454.45120.

PicketT G. 1945. Equations for computing elastic constants from flexural and torsional resonant frequencies of vibration of prisms and cylinders. ASTM Proceeding 45: 846-865.

Portela MS. 2014. Estudo das propriedades acústicas da madeira amazônica Marupá para tampo de violão. MSc thesis. Universidade Federal De Santa Catarina (UFSC), Florianópolis.

Rocha KR \& JÚNIOR AJB. 2018. Repeated measures ANOVA and its assumptions: a step-by-step analysis of an experiment. Perspectivas da Ciência e Tecnologia 10: 29-51. doi: http://dx.doi.org/10.22407/1984-5693.

Rousseeuw PJ \& Huber M. 2018. Anomaly detection by robust statistics. WIREs Data Mining and Knowledge Discovery 8: e1236. doi: 10.1002/widm.1236. 
Slooten H Van Der \& Souza MR. 1993. Evaluation of Selected Amazonian Wood Species for Musical Instrument Manufacture. National Institute of Amazonian Research (INPA), Manaus.

Spinner S \& Tefft WE. 1961. A method for determining mechanical resonance frequencies and for calculating elastic moduli from these frequencies. ASTM Proceeding 61: 1221-1238.

Spinner S, Reichard TW \& Tefft WE. 1960. A comparison of experimental and theoretical relations between Young's Modulus and the flexural and longitudinal resonance frequencies of uniform bars. Journal of Research of the National Bureau of Standards - A Physics and Chemistry. 64: 147-155. http://dx.doi. org/10.6028/jres.064A.014.
Uetimane JR U \& Alic AC. 2011. Relationship between mechanical properties and selected anatomical features of Ntholo ("Pseudolachnostylis maprounaefolia"). Journal of Tropical Forest Science 23: 166-176.

Valente BMDRT, Evangelista WV, Silva JDC \& Lucia RMD. 2013. Variabilidade radial e longitudinal das propriedades físicas e anatômicas da madeira de angico-vermelho. Scientia Forestalis 41: 485-496.

YARED JAG. 1992. Silvicultura de algumas espécies nativas da Amazônia. Anais do Congresso Florestal Brasileiro 12: 119-122.

Zobel BJ \& Sprague JR. 1998. Juvenile Wood in Forest Trees. Springer Series in Wood Science. Springer, Berlin. doi: 10.1007/978-3-642-72126-7. 